\title{
Perfection of the public hearings procedure in Russia: two-stage model
}

\author{
Nina Danilina ${ }^{1, *}$, and Zinaida Ivanova ${ }^{1}$ \\ ${ }^{1}$ Moscow State University of Civil Engineering, Yaroslavskoye shosse, 26, Moscow, 129337, Russia
}

\begin{abstract}
The article deals with the relevant problems of public hearings procedure on urban development projects. The authors examined the existing European practice of self-government of citizens, their participation and role in public hearings, identified the positive aspects of the organization of consensus conferences in Denmark. There are the results of conducted sociological studies using questionnaires, focus groups (group discussions), expert survey and content analysis addressed to identify the attitude of residents of different cities of the Russian Federation to public hearings,. A significant amount of primary and secondary data was collected, which allowed to establish a real picture of violations during public hearings procedure, as well as to collect critical comments and suggestions of citizens. Having carefully analyzed the existing legislative documents, the Urban development code of the Russian Federation in the new edition (2019), the authors developed a two-stage model of public hearings procedure, offering a new methodological approach to the organization and conduct of public hearings and public discussions.
\end{abstract}

\section{Introduction}

The common widespread practice of participatory democracy and deliberative democracy in modern society is public hearings. There are a lot of different form in different countries: consensus conferences, citizen juries, public discussions and others. The scope of application of public hearings as the citizens self-government form is extremely wide: many medical, environmental, budgetary, financial, administrative problems are solved with the participation and taking into account public opinion. The most widely this forms is requested and applied in town-planning and city management. For example, the Town planning Code of the Russian Federation specifies (Art. 5.1.) "public discussions, public hearings are held on draft master plans, draft rules of land use and development, land planning projects, land surveying projects, draft rules of landscaping, draft decisions on granting permission for conditionally permitted use of land or capital construction, draft decisions on granting permission to deviate from the limit parameters of permitted construction, reconstruction of capital construction" . This underlines their importance and

*Corresponding author: nina_danilina@mail.ru 
high level of the attention to the procedure of public hearings both from city society and government [1].

All over the world, there are different procedures of public hearings fixed in laws and government decisions from the national strategy to specific municipal town planning regulations. In Russia, this public hearings procedure is determined by the Charter of the municipality and / or normative legal acts of the representative body of the municipality. At the same time, general idea, methodological approach and main principles to the process organization coincide with world experience in common.

The purpose of this article is to develop the advanced version of the public hearings procedure for urban planning practice of the Russian Federation based on world experience.

There are a lot of problems with the organization of public hearings in Russia. The main is the lack of legal status of the public hearings decisions and results: the Head of the municipality have the authority to accept or to reject the final conclusion without any approval. The common situation is when the attention is given only to insignificant remarks and offers and really serious offers concerning realization of the rights of citizens to a comfortable city environment have been ignored really. This is a contradiction with Article 42 of the Constitution of the Russian Federation that ensures the right of every citizen to "a favorable environment, reliable information about its condition and compensation for damage to health or property" and the Town-planning code of the Russian Federation that confirms the right of residents to create a favorable urban environment and prescribes the channels of "participation of citizens and their associations in the implementation of town-planning activities, ensuring the freedom of such participation". Other problems are related to the procedure of appointment of public hearings, notification of the population about their time and place, the formation of the organizing Committee, the list of admitted persons to the hearings, the work of the media. That's why it is so important to form a methodological support for public hearings procedure as a legal institution, including its clear regulation, the definition of the membership and legal status of participants, the results acceptance procedure, responsibility of the authorities to the population..

The discussion how to reach the aim of democracy in the field of population involvement in the management of urban processes have been well developed in scientific researches and analytics focused on particular features of this involvement in a particular legal system of a state. The value of these discussions is that they reveal the advantages and disadvantages of national systems of democracy and at the same time represent the practice of self-government. It is the relevant challenge for sociologists and jurists, urban planners and representatives of the city and municipal authorities to take advantage of existing experience and adapt certain practices in a specific environment $[1,2,3,4]$.

Nowadays there are a lot of publications about the organization and conducting of public hearings in different countries. For Russia, the experience of foreign countries, primarily European, is the point of interest, so first of all, analytical articles on the organization of consensus conferences and public discussions in Europe are considered [59].

The good example is Denmark experience of a consensus conference on "Consumption and the environment". The author notes that the basic principle of the Danish Technology Council is that technology assessment should include the wisdom and experience of ordinary people / non-professionals integrated with knowledge and tools of experts. The consensus conference creates a bridge between members of the public society, stakeholders and experts. The result is a consensus document that is available to decision makers and the public. The author focuses on ensuring the legality of the results of the consensus conference. The article as a whole is a contribution to the development of the methodology for organizing democratic debates and political decision-making [10]. 
The other new trend is to use Smart city technologies for the organization of public hearings and wide involvement of citizens in it. The authors of the article "Fundamentals of citizen participation in planning: from dialogue to intellectual tools focus their attention the digital tools and technologies for sustainable urban planning. [11]. Expanding the institutions of citizens self-government for involvement into urban development projects through modern digital technologies is one of the important factors in the formation of a sustainable settlement.

The Spanish experience in the article "On the way to intelligent sustainable cities: an overview of the role that digital civic participation can play in promoting social sustainability " concludes that information and communication technologies used in citizen participation processes will make a significant contribution to social sustainability [12].

Finally, it is necessary to highlight the publications that pose acute contemporary problems and shortcomings of the organization and conduct of public hearings in our country $[13,14]$. Among them, the issue related to the results of public hearings acceptance is of particular importance. How is the final document of public hearings "born"? In practice, there are cases, the author notes, when the organizing Committee draws up a conclusion based on the results of the hearings that don 't reflect the full range of expressed opinions and reflect only the "right" opinion of the Organizer. In this case, public hearings simply lose their meaning, and citizens trust in this institution is also lost. Many researchers draw their attention to the disappointment of the citizens with the action of the Institute of public hearings and proposes measures aimed at improving the efficiency of public hearings [15].

\section{Materials and Methods}

The study was carried out a combination of theoretical and empirical analysis, complementary development of fundamental and applied problems. The comparative legal analysis of Russian and foreign legislation of self-government institutions and organization of public hearings in different countries was carried out. This approach provided the comparison of the specific rules for the organization of public hearings in different legal systems.

The methods of the documents analysis and the secondary data analysis were used for acquaintance with experience of public hearings process in of town-planning. There was the course of sociological surveys (questionnaires, focus groups) of different respondent's categories to identify the problems existing in the Russian practice of public hearings. This analysis became the primary data. Next, we used complex study to evaluate the complexity of the problem. Town planning projects have affected various aspects of urban life, have covered a set of indicators of the urban environment sustainability and have underlined the necessity of providing the rights of citizens. Methods of urban analysis such as mathematical and graphical-analytical methods of investigation of urban systems allowed to investigate the prevailing comprehensive urban planning situation and submitted for discussion the draft plan areas. The method of legal modeling allowed to construct a model of public hearing on the project of territory planning, aimed at creating the optimal version of the approved project.

\section{Results}

Any urban development project should, on the one hand, meet the needs of the city in the development and economic efficiency of urban areas; on the other hand, meet the needs of the population in the formation of comfortable and safe living conditions. 
Conflict situations arise quite often when the wishes of residents don 't correlate with the decisions of the authorities on the development of the territory or urban infrastructure. Social work that was discussed in focus groups postgraduates-urban planners, and postgraduates-architects from different cities of Russia currently working in architectural and urban planning organizations, showed that the opinion of citizens on the topic of urban problems is not implemented or is not fully implemented in almost all discussed cities. In many cases people's opinion was interesting on the stage of an already developed project, when it is too late to make changes, large amounts of money and resources are invested in the project. As a result, projects are implemented in mode that is beneficial for the government and the developer. It causes indignation of inhabitants, discontent with the power and social conflicts. However, the unite opinion of all respondent from Krasnodar city is that only small percentage of population is involved in the management of urban activity and decision-making. Another wide spread opinion is that citizens are not used to express their will in architecture and urban planning, because they think that (although, it is) everything is decided by the municipality and developers. The Institute of the General Plan of Moscow representative (participant of the discussion) says that at present there are a lot of programs on city residential areas renovation. and these projects if they will be discussed at public hearings, will meet citizen's criticism and serious objections. However, the renovation program is built on a "top-down" vertical and urban planners cannot do anything about it. There was the necessity to conduct pre-project studies to discuss many issues with the residents, to prepare them, to come to a compromise, to smooth out contradictions. However, as it was noted by the speaker, "this may be in the belief that public hearings - a working institution, and not perceived by the authorities as formal."

These examples show that violations of the rights of citizens to express their needs meet obstacles. Meanwhile, serious decisions regarding a particular urban environment can only be made by the majority of the inhabitants of that environment. One of the participants of the discussion also added that there was no accounting for the necessary documents for the approval of the project by age, occupation, qualification in the discussed issues, any legal literacy, no representation of social groups with business alternative proposals and no leader's opinion.

These and other data were obtained in the course of a sociological survey, content analysis of various sources, which highlights the opinion and complains of citizens about the imperfection of the laws, insufficiently developed procedures for public hearings and the lack of legal status of the decisions taken.

There is the analysis of the existing structure of public hearings process in Russia from the point of view: stage - action - responsibility - documentation support of public hearings procedure. 


\begin{tabular}{|c|c|c|c|}
\hline Stage & Action & Responsibility & Official document \\
\hline \multirow{2}{*}{ 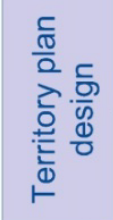 } & $\begin{array}{l}\text { Initiation of territory plan } \\
\text { design process }\end{array}$ & $\begin{array}{l}\text { Authorities/ } \\
\text { Investor }\end{array}$ & $\begin{array}{l}\text { City Master plan, } \\
\text { Land use regulations, } \\
\text { Technical regalements }\end{array}$ \\
\hline & $\begin{array}{l}\text { Order and payment for the } \\
\text { territory plan design }\end{array}$ & $\begin{array}{l}\text { Authorities costs/ } \\
\text { investor costs }\end{array}$ & $\begin{array}{l}\text { Main territory plan, } \\
\text { Supporting } \\
\text { documentation }\end{array}$ \\
\hline \multirow{2}{*}{ 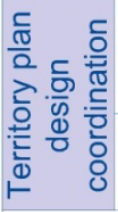 } & $\begin{array}{l}\text { Verification of compliance } \\
\text { with regulatory and } \\
\text { technical requirements }\end{array}$ & $\begin{array}{l}\text { Department, responsible } \\
\text { for urban planning policy } \\
\text { in the city }\end{array}$ & $\begin{array}{c}\text { Permission / Deviation of } \\
\text { the documents }\end{array}$ \\
\hline & $\begin{array}{c}\text { Preliminary stage of } \\
\text { documents preparing for } \\
\text { public hearings }\end{array}$ & City Major & $\begin{array}{l}\text { Permission for public } \\
\text { hearings }\end{array}$ \\
\hline \multirow{2}{*}{ 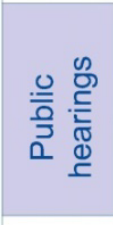 } & Public hearing process & $\begin{array}{l}\text { Authorities, legal organizations, } \\
\text { private people registered on the } \\
\text { territory of public hearings } \\
\text { discussion }\end{array}$ & $\begin{array}{l}\text { Main territory plan, } \\
\text { Supporting } \\
\text { documentation }\end{array}$ \\
\hline & $\begin{array}{c}\text { Preparing final resolution on } \\
\text { territory plan }\end{array}$ & Municipal authorities & $\begin{array}{l}\text { Conclusion with } \\
\text { analysis of proposals } \\
\text { and comments }\end{array}$ \\
\hline 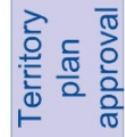 & $\begin{array}{l}\text { Territory plan } \\
\text { confirmation }\end{array}$ & City Major & $\begin{array}{l}\text { Official resolution } \\
\text { for territory plan } \\
\text { confirmation }\end{array}$ \\
\hline
\end{tabular}

Fig. 1. Existing official public hearings procedure.

This analysis underlined the main problem and conflict points that should be developed:

1. The lack of pre-project work with the residents to gather their opinions and desires until the beginning of the development of the urban project;

2. The lack of a full set of documents of the town-planning project reflecting all design decisions in information available for perception by ordinary people. There are cases of hiding contradictory information that can cause public uproar. Often the project itself is not carefully verified and contains errors.

3. Serious violations are observed in the notification of residents. Announcements about the location of the exhibition and the beginning of public hearings should be published on the official website, which hosts the project and information materials to it, as well as on information stands in crowded places. In fact, not all citizens of the district constantly use the Internet, and the announcement in the local newspaper is not published on the first page. Announcements on information stands at entrances of houses are not hung out. The customer is not interested in a broad discussion of their projects and tries to hide information. Most of the population of the district is not informed.

4. The process of public hearings is held in violation of moral and ethical, organizational rules. Activists of the city of Moscow note the facts of prevention in halls of hearings of inhabitants of the area concerning which public hearings are carried out. Often at hearings there are people working in the given territory, but not living and having no property. There is the presence of invited from the organizations of the district or completely strangers ("imported extras", in the words of one of the members of the initiative group). Some participants may not be allowed to the microphone, so as not to "sharpen" the existing problems in the project, which worsen the environmental situation of the area or create transport problems. 
5. The conclusion on public hearings contains only those amendments and proposals that suit the customer or the municipality. The content analysis of the published protocols of public hearings and conclusions reveals the fact of absence of reasoned explanations of the organizer of public hearings of inexpediency of the account of the made offers and remarks and conclusions by results of public hearings.

The result of the perfection became the Two - stages public hearings procedure (fig.2).

It is more longer procedure, but should provide the democratic approach to taking into account the population opinion on urban development projects. The main character features are:

1. The time period of public hearings or public discussions may be extended up to 4 months to allow residents of the territories to thoroughly familiarize themselves with the project, to conduct an independent environmental, technical and social expertise, to make suggestions and comments. In the civil code of the Russian Federation the term of public discussions or public hearings on draft rules of improvement of territories from the date of publication of the notification on the beginning of public discussions or public hearings to the date of publication of the conclusion on results is defined by the Charter of municipality and (or) the regulatory legal act of representative body of municipality and cannot be less than one and more than three months.

2. Holding two meetings of participants: at the initial stage of project development and after making comments and suggestions. Holding the first public hearing is necessary to identify unintended design errors, for example, in calculations and estimates. It is difficult to change the finished version of the project put up for public hearing, because the work of designers and certain material and financial resources are invested in it. Consideration of the initial version of the project will avoid unnecessary waste of resources.

3. The possibility to include the work of independent experts, volunteers, specialists for a fee. Also it is necessary to take an advantage of co-design opportunities here.

4. Mass notification using smart technologies. In particular, those digital programs that are used in the EMERCOM of the Russian Federation-notification by SMS are available. It is possible to notify all residents of the territory in which a public hearing or public discussion is held. It is also proposed to use city activists and volunteers to locate distribute the information on information stands near the public entrances. It is necessary to establish rules and regulations to ensure the availability of information about public hearings (mandatory requirements for information: place, time, agenda, etc.).

5. Increased requirements for the organizing Committee, which should include people professionally trained to conduct public hearings; clearly define their functions, responsibilities and the measure of responsibility for their implementation;

6. Development of a legal framework for the activities of independent experts involved in the project evaluation. Expert groups should be formed both from professionals living in the territory under consideration and from specialists invited from outside and not personally interested in accepting or rejecting this project. Such a composition is necessary for a deeper analysis of the environmental and social consequences of the project. Experts invited from the outside may not know the specifics of the area, the conditions of comfort or discomfort, as they have not experienced the impact of the factors of the environment

7. Strict accounting of participants in public hearings or public relations. To ensure the control of public activists over the passage to the hall for public hearings. To provide a legal framework for the work of representatives of the city media, independent journalists, broadcasting of meetings of public hearings.

8. Last stage is the official approval of the public hearings protocol. It is important to fix the obligatory principle in the special law or regulations on public hearings to take into account the results of public hearings and public discussions. This principle is: if more than $20 \%$ of the population whose rights are affected by the management decision submitted for 
discussion expressed their disagreement with the project, it is necessary to raise the issue of revision of the project; it is necessary to make a decision to ban the adoption of the project, against which more than $50 \%$ of the population of the territory expressed their opinion.

\begin{tabular}{|c|c|c|c|}
\hline Stage & Action & Responsibility & Official document \\
\hline \multirow{2}{*}{ 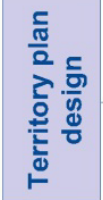 } & $\begin{array}{l}\text { Initiation of territory plan } \\
\text { design process }\end{array}$ & $\begin{array}{l}\text { Authorities/ } \\
\text { Investor }\end{array}$ & $\begin{array}{l}\text { City Master plan, } \\
\text { Land use regulations, } \\
\text { Technical regalements }\end{array}$ \\
\hline & $\begin{array}{l}\text { Order and payment for the } \\
\text { territory plan design }\end{array}$ & $\begin{array}{l}\text { Authorities costs/ } \\
\text { investor costs }\end{array}$ & $\begin{array}{l}\text { Main territory plan, } \\
\text { Supporting } \\
\text { documentation }\end{array}$ \\
\hline \multirow{2}{*}{ 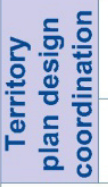 } & $\begin{array}{c}\text { Verification of compliance } \\
\text { with regulatory and } \\
\text { technical requirements }\end{array}$ & $\begin{array}{l}\text { Department, responsible } \\
\text { for urban planning policy } \\
\text { in the city }\end{array}$ & $\begin{array}{l}\text { Permission / Deviation of } \\
\text { the documents }\end{array}$ \\
\hline & $\begin{array}{c}\text { Preliminary stage of } \\
\text { documents preparing for } \\
\text { public hearings }\end{array}$ & City Major & $\begin{array}{l}\text { Permission for public } \\
\text { hearings }\end{array}$ \\
\hline \multirow{8}{*}{ 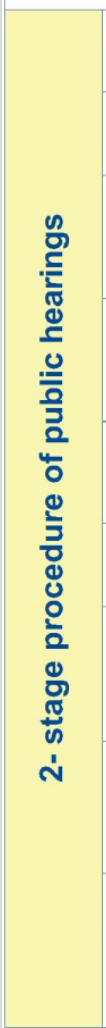 } & \begin{tabular}{|c|}
$\begin{array}{c}\text { Placement of the project on } \\
\text { the official website and / or } \\
\text { opening of the exhibition }\end{array}$ \\
$\begin{array}{c}\text { Public notification of the } \\
\text { population in all accessible } \\
\text { forms }\end{array}$ \\
\end{tabular} & Municipal authorities & $\begin{array}{l}\text { Main territory plan, } \\
\text { Supporting } \\
\text { documentation }\end{array}$ \\
\hline & $\begin{array}{c}\text { 1-st } \\
\text { Preliminary stage } \\
\text { of public hearings } \\
\text { procedure }\end{array}$ & $\begin{array}{l}\text { Authorities, legal } \\
\text { organizations, private people } \\
\text { registered on the territory of } \\
\text { public hearings discussion }\end{array}$ & $\begin{array}{l}\text { Fixation of the } \\
\text { procedure process } \\
\text { protocol }\end{array}$ \\
\hline & $\begin{array}{l}\text { Collecting and analysis of } \\
\text { all comments }\end{array}$ & Municipal authorities & $\begin{array}{l}\text { Resolution on the } \\
\text { preliminary conclusions } \\
\text { on the territory plan } \\
\text { design }\end{array}$ \\
\hline & $\begin{array}{c}\text { Expert analysis of the } \\
\text { resolution on the preliminary } \\
\text { conclusions on the territory } \\
\text { plan design }\end{array}$ & Expert commision & Final expert protocol \\
\hline & $\begin{array}{c}\text { Preparation and publishing of } \\
\text { the Protocol on the } 1 \text {-st stage } \\
\text { public hearings results }\end{array}$ & Municipal authorities & $\begin{array}{c}\text { Final protocol, } \\
\text { Renovated territory plan } \\
\text { design }\end{array}$ \\
\hline & $\begin{array}{l}\text { 2-nd } \\
\text { Main stage } \\
\text { of public hearings } \\
\text { procedure }\end{array}$ & $\begin{array}{l}\text { Authorities, legal } \\
\text { organizations, private people } \\
\text { registered on the territory of } \\
\text { public hearings discussion }\end{array}$ & $\begin{array}{l}\text { Fixation of the } \\
\text { procedure process } \\
\text { protocol }\end{array}$ \\
\hline & $\begin{array}{l}\text { Collecting and analysis of } \\
\text { all comments }\end{array}$ & $\begin{array}{l}\text { Joint work of municipal } \\
\text { authorities and experts }\end{array}$ & $\begin{array}{l}\text { Resolution on the final } \\
\text { conclusions on the } \\
\text { territory plan design }\end{array}$ \\
\hline & $\begin{array}{c}\text { Final version of territory } \\
\text { plan design with obligatory } \\
\text { implementing of the expert } \\
\text { conclusions }\end{array}$ & Municipal authorities & $\begin{array}{l}\text { Final protocol on the 2-st } \\
\text { stage public hearings } \\
\text { results, } \\
\text { Renovated territory plan } \\
\text { design }\end{array}$ \\
\hline 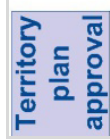 & $\begin{array}{l}\text { Territory plan } \\
\text { confirmation }\end{array}$ & City Major & $\begin{array}{l}\text { Official resolution } \\
\text { for territory plan } \\
\text { confirmation }\end{array}$ \\
\hline
\end{tabular}

Fig. 2. Proposals on Two-stages public hearing procedure.

This approach was the result of joint work of socialists, jurists, urban planners, experts and active citizens and aimed on democratic way of Russia development. 


\section{Discussion}

The presented two-stage model of public hearings is developed on the basis of a broad study of existing problems and world experience, which has already found ways to solve them. This model requires further research to address the complex legal, social, procedural and urban aspects necessary for its adjustment and most effective work. The scientific novelty of the work is that supporting the ideas of other researchers about the need for deeper inclusion of the population in urban planning for the development of democracy in Russia, we propose and justify a new way, which is a quite new experience.

\section{Conclusions}

Public hearings are a public institution, which is a special phenomenon in the development of democratic processes, despite the presence of ancient roots going back to ancient Greece. In Western democracies, there are different types of public hearings, the procedure is worked out more carefully under the control of civil society organizations. Russia as a part of developed world is also on this way of development of civil society and searches of direct municipal democracy forms as alternatives to strengthening of authoritarianism and dictatorship of state bodies, blocking of ways for corruption and monopolization of the power. That is why we should develop the public hearings procedure and delete those serious violations in organization that were revealed in this research.

The reported study was funded by RFBR according to the research project № 18-011-01004.

\section{References}

1. B. Checkoway, The J. of Appl. Beh. Scie., 17 (4), 566-574 (1981) https://doi.org/10.1177/002188638101700411

2. P. Mikuli, G. Kuca, Liverpool Law Review, 37 (1-2) , 1-17 (2016) https://doi https://doi.org/10.1007/s10991-016-9177-z

3. M.P. Ram Mohan, H. Pabreja, Ec. and Pol. Week., 51 (50) (2016) https://www.epw.in/journal/2016/50/special-articles/public-hearingsenvironmental-clearance-process.html

4. T. Lorsuwannarat, Int. J. of Pub. Ad., 40 (5), 385-400 (2017) https://doi.org/10.1080/01900692.2015.1126730

5. A.M. Ríos, B. Benito, F. Bastida, Aust. J. of Pub. Ad., 76 (1), 48-64 ( 2017) DOI: $10.1111 / 1467-8500.12197$

6. F. Saab , P. Bermejo, G. Garcia, J. Pereira, S. Silva, J. of Ent. Inf. Man., 31 (5), 796-814 (2018) https://doi.org/10.1108/JEIM-11-2017-0169

7. C. Matthew, A. Wiek, B. Kay, J. Harlow, Sustainability 7(7), 8709-8728 (2015) https://doi.org/10.3390/su7078709

8. E. Falco, Int. J. of E-Plan. Res. (IJEPR), 7(3) (2018) DOI: 10.4018/IJEPR.2018070105

9. J. Barlow, Pub. Part. in Urb. Develop.: The Eur. Exp., Policy Studies Institute. 160 (1995)

10. L. Zurita, Land Us. Pol., 23(1), 18-25 DOI:10.1016/j.landusepol.2004.09.002 
11. D. Horgah, B. Dimitrijević, Sust. Cit. and Soc. 48, 101550 (2019) https://doi.org/10.1016/j.scs.2019.101550

12. I. Bouzguenda, Ch. Alalouch, N. Fava, Sust. Cit. and Soc., 50, 101627 (2019) https://doi.org/10.1016/j.scs.2019.101627

13. B. Gladarev, Attempts to Overcome 'Public Aphasia': A Study of Public Discussions in Russia at the Beginning of the Twenty-first Century. In N. Vakhtin \& B. Firsov (Eds.), Public Debate in Russia: Matters of (Dis)order, 167-205 (Edinburgh University Press, 2016)

14. D. Zupan. Eur. Reg. (Germany, 22 ( 1-2) 39-52, 2015) ER2014-1-2Zupa.pdf

15. O. Pavlycheva, Matec Veb of Conf., 106, 01018 (2017) doi: $10.1051 /$ matecconf/201710601018 